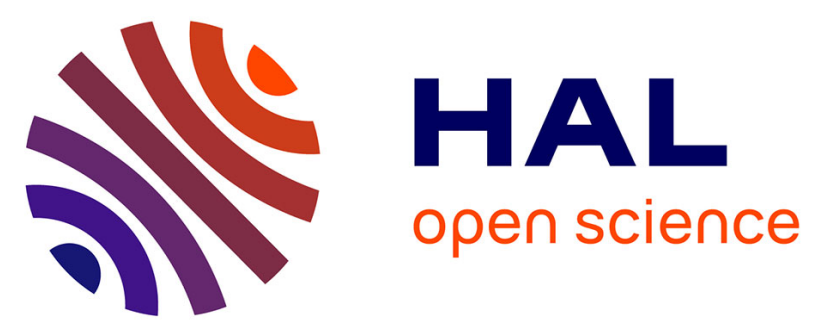

\title{
Online Campaigning in France, 2007-2012: Political Actors and Citizens in the Aftermath of the Web.2.0 Evolution
}

\author{
Karolina Koc-Michalska, Rachel Gibson, Thierry Vedel
}

\section{To cite this version:}

Karolina Koc-Michalska, Rachel Gibson, Thierry Vedel. Online Campaigning in France, 2007-2012: Political Actors and Citizens in the Aftermath of the Web.2.0 Evolution. Journal of Information Technology and Politics, 2014, pp.24. 10.1080/19331681.2014.903217 . hal-01096334

HAL Id: hal-01096334

https://hal-audencia.archives-ouvertes.fr/hal-01096334

Submitted on 17 Dec 2014

HAL is a multi-disciplinary open access archive for the deposit and dissemination of scientific research documents, whether they are published or not. The documents may come from teaching and research institutions in France or abroad, or from public or private research centers.
L'archive ouverte pluridisciplinaire HAL, est destinée au dépôt et à la diffusion de documents scientifiques de niveau recherche, publiés ou non, émanant des établissements d'enseignement et de recherche français ou étrangers, des laboratoires publics ou privés. 
Online campaigning in France 2007-2012: political actors and citizens in the aftermath of the web.2.0 evolution

\author{
Karolina Koc-Michalska \\ Rachel Gibson \\ Thierry Vedel
}

\title{
Author's version
}

\begin{abstract}
This paper examines political elites and citizens use of the web during the 2007 and 2012 French presidential campaign particularly with the aim of testing the normalization hypothesis at two levels of analysis - supply and demand. It is based on a quantitative content analysis of the candidates' websites and two surveys of French Internet users. The results present a challenge to the normalization thesis at the elite level in that despite a strong division in online performance between the major and other candidates in 2007, by 2012 the minor candidates outperformed their major counterparts Among voters the results also run somewhat contrary to normalization with a weakening in the significance of socio-demographic factors in determining traditional types of online engagement. In addition, the new social media sphere appears to encourage younger and less politicized citizens to participate. The importance of prior political attitudes such as interest and trust, however, remain strong.
\end{abstract}

Keywords: French presidential election, Internet, political engagement, web.2.0, electoral behaviour, political communication, online strategy 


\section{INTRODUCTION}

Views on the influence of the Internet on civic and political life in democratic regimes differ. At the extremes one can point to pessimists who see it as a danger to democracy (Morozov, 2013) and optimists who view it as the means to regenerate political life (Coleman \& Gøtze, 2001). Less extreme versions of these dystopian and utopian views are the mobilization or equalization and normalization or reinforcement hypotheses. Both sides of the argument follow a more inductive and empiricist logic with the former setting out the idea that the internet brings new and less well represented voices into the political process, while the latter sees that the Internet changes very little and if anything may be reinforcing the position of the more powerful and resource rich. Both sets of concepts equalization/mobilization and normalization/reinforcement - have now been tested in a range of studies at both elite and mass level. In the course of this paper we seek to apply them to the case of the French 2007 and 2012 Presidential election.

The two previous French presidential elections provide an ideal opportunity to test these two interpretations of the internet's role in the developed democracy from elites' and citizens' perspective. First, from the perspective of digital campaigning, France has been seen as among the more advanced nations in candidates uses of the technology at the national level, despite a rather cautious start. At the beginning of the $21^{\text {st }}$ century Internet use was still quite low among the general public. This was in part due to the popularity of Minitel, a popular French-origin network that preceded the Web and allowed for information searching and exchange of the messages among users. This reticence was mirrored among elites and limited attention was given to online communication by parties and candidates. The 2002 Presidential campaign for example saw a very conservative use of digital tools in the election (Vedel \& Cann, 2008). Online campaigning really started to gain in prominence during the 2005 referendum on the European constitution (Bousquet, 2009). It was the Presidential campaign of 2007, however, and particularly the activities of the Socialist candidate Ségolène Royal and her team that placed online campaigning in France on the global map. Through her clever use of blogging software she built up a 
network of activist support that became known as 'Segoland' and that echoed the success of the 'netroots' movement that propelled Howard Dean to frontrunner status in the U.S. Presidential primaries of 2004. Indeed the electoral cycle of the first decade of the $21^{\text {st }}$ century interwove the French Presidential elections with American elections of 2008 and 2012. Both countries saw considerable technological innovation and the extensive usage of the new media to build communities around the candidate in a somewhat reciprocal fashion (Lilleker \& Jackson, 2011; Nam \& Stromer-Galley, 2012). By 2012 the web had become an integral part of candidate strategies. Among citizens it had similarly become an almost indispensable tool. The pace of usage of the Internet more than doubled during the last decade, from $30 \%$ in $2002,66 \%$ in 2007 to $83 \%$ users among French society in $2012 .^{1}$

In institutional terms the French system also presents a highly compelling case for analyzing the adoption of, and public attention to internet campaigning. The semi-presidential political system demands a highly visible and personalised style of electoral campaigning that is similar to the American presidential campaign. Such characteristics have been seen as helping to accelerate the adoption of the new campaign techniques in contrast to the slower party-centric parliamentary or Westminster style model (Anstead \& Chadwick, 2008). Moreover one important area of contrast to the U.S. lies in the more limited finances available to candidates. French law imposes ceilings on expenditures permitted in elections, and resources available to candidates depend on the supporting party financing, and due to the state reimbursement, also to the number of votes obtained ${ }^{2}$. While this may slow down some of the advances in the use of most cutting edge techniques it also provides for a more genuinely multi-candidate system and a spread of varying financial resources that means a test of the normalization vs. mobilization

\footnotetext{
${ }^{1}$ http://data.worldbank.org/indicator/IT.NET.USER.P2?page=2

2 For the 2012 presidential election, limits were $€ 16.9$ million for the candidates present in the first round and $€ 22.5$ million for those present in both rounds,. Sponsorship from corporations is not allowed. The campaign is financed by the party, donations collected from the individuals and state reimbursement. All candidates are eligible to be reimbursed by the state for their campaign spending according to the number of votes obtained (with the amounts depending on whether the party got more or less than 5\% of votes. For more details: http://www.viepublique.fr/decouverte-institutions/institutions/fonctionnement/president-republique/comment/comment-estfinancee-campagne-electorale.html (accessed June 2013)
} 
argument becomes more meaningful (see Vedel \& Cann, 2008) ${ }^{3}$. A further helpful trait of French Presidential elections in this context is that they generate substantial attention and interest among voters. In the first round of the 2007 and 2012 Presidential election $84 \%$ and $79.5 \%$ of the French electorate respectively cast their vote. ${ }^{4}$ Candidates thus have a strong incentive to ensure they present an appealing and highly visible web presence.

Finally in practical terms this study expands the literature by widening the geographic focus to cover a nation that despite its increasing prominence in the arena of digital campaigning has not been the subject of much systematic analysis. The fact that we compare and profile changes in candidate and citizen online activism across two election periods adds an important over time element to the analysis that allows us to undertake a more in-depth look at the questions normalization vs mobilization. We proceed by first comparing the online political communication strategies of candidates during the 2007 and 2012 French presidential elections. We look particularly at the information and engagement components of their online campaigns and in 2012 we also compare their web.2.0 communication strategies. Were smaller players managing to compete with their major counterparts in terms of the quality of the web campaigns they were able to provide (mobilization), or did the latter simply dwarf their efforts and dominate the debate (normalization)? We then profile levels of online political engagement and the drivers behind citizen involvement in the e-campaign. We do so using two cross-sectional survey data sets that measure traditional types of online engagement via web-participation as an index (eengagement) for 2007 and 2012) and what we term an 'e2-engagement' index that is based on social media activity and applies only to 2012. We conceptualize the 'e-engagement' as the traditional online activities, most often practiced through websites. The 'e2-engagement' represents those forms of activities which are performed through platforms (social network sites) which require a more structured

\footnotetext{
${ }^{3}$ Most of the presidential candidates or parties supporting them were present online already in 2002 when only one out of fifteen candidates did not declare any expenses for the online platforms (Vedel \& Cann, 2008).

${ }^{4}$ The tendency of the high participation in Presidential elections is rather stable among French citizens. Turnout: $200272 \%$ in the first round and $80 \%$ in the second round; $199578 \%$ and $80 \% ; 198881 \%$ and $84 \% ; 198181 \%$ and $86 \% ; 197484 \%$ and $87 \% ; 196978 \%$ and $69 \% ; 196585 \%$ and $84 \%$.
} 
and personalized manner of engagement through the establishment of profile or account. Such platforms go beyond simple experience of communication (receiving or sending information) but rather offer the possibility of community creation (Koc-Michalska \& Lilleker, 2013). Even if communication is only received (passive activity) then it is received in a specific context, often shared or posted by 'friend' so its social impact may have high importance (Bond et al., 2012). Finally, e2 engagement implies forms of horizontal communication among citizens, while e-engagement is mostly based on vertical communication between elites and citizens. In looking at these forms of citizen engagement we focus on the key question of how far they saw the 'usual faces' in terms of drawing in the already politically active (normalization) versus the extent to which they encouraged political involvement of new segments of society (mobilization). The work is based on ongoing elite and mass level internet election studies conducted by the Centre for Political Research (CEVIPOF) ${ }^{5}$.

\section{THE INTERNET DURING ELECTORAL CAMPAIGNS}

\section{Political elites and Internet campaigning}

Scholars have traced the evolution in candidates and parties use of websites, e-mails and most recently social media for over a decade and a half now and it is clear that it has become an everyday part of political as well as societal communication. Research on the role the Internet plays in political communication in general and electoral campaigning in particular is growing in reach and theoretical depth. Studies have evolved from largely descriptive profiles of online campaigns in a single election (e.g. Margolis et al., 1997; Gibson \& Ward, 1998; Carlson \& Djupsund, 2001) to differentiating various modes of web campaigning (web 1.0 and web 2.0) (Carlson \& Strandberg, 2008; Druckman et al., 2010; Schweitzer, 2011; Hamilton \& Tolbert, 2012) however application of a comparative research design

\footnotetext{
${ }^{5}$ Elite level studies managed by the author in April 2007 and 2012 within the 'Online campaigning project' run by author with D. Lilleker Bournemouth University. Mass level studies: survey 'Internautes et information' January 2007, 'Mediapolis' March 2012 (ANR 2008 - 2012 project), CEVIPOF, Sciences-Po Paris.
} 
(Gibson et al., 2003; Foot et al., 2007; Lilleker et al., 2011; Colombo et al., 2012; Vergeer et al., 2013a, b; Vaccari, 2013) are still rare.

In the course of these analyses something of a consensus has emerged that the dominant trend in political actors' adaptation to the new media is the normalization or 'politics as usual' thesis (Resnik, 1998; Margolis \& Resnick, 2000). For parties this is demonstrated typically by analyses of their web presence and site content which show that minor parties and candidates are less frequently online, and when they are, have a less sophisticated presence and lower visibility (Gibson et al., 2003; TkachKawasaki, 2003; Xenos \& Foot, 2005; Kluver et al., 2007; Schweitzer, 2005, 2008, 2011; Vaccari, 2008; Lilleker et al., 2011).

More recently the possibility of a return to the mobilization scenario with the rise of web 2.0 or social media tools has been highlighted (Gueorguieva, 2007; Kalnes, 2009; Strandberg, 2013). Social media and particularly SNS provide a more organizational and activist resource through which smaller parties can build a support base and larger network than would be possible offline to spread their message. As Chadwick (2012) has argued the social media environment may be fostering a new 'a lowthreshold communication environment' and a new breed of virtual opinion leaders that help in transmitting political attitudes, both offline and online (Norris \& Curtice, 2008). Recent empirical work conducted in Australia (Gibson \& McAllister, 2014) supports this idea in that while the two major parties were more visible through personal websites, candidates from the Greens were more active via social media and importantly, appeared to gain some electoral advantage from their use of these newer social media technologies.

Based on these findings from the literature on web campaigning from the 'supply' side perspective we set out the following three research questions to be examined in the context of the 2007 and 2012 French Presidential elections. The first two are primarily descriptive:

RQ1. How far did candidates promote active engagement and interactivity versus information provision in their homepages? What are the changes between 2007 and 2012 elections' performance?

RQ2: To what extent did candidates exploit the interactive possibilities of web.2.0 tools in 2012? 
The final question is more analytical and draws the findings together from the first two to address the core question of the paper:

RQ3: To what extent does the content and quality of candidates online presence across the two elections show support for normalization or mobilization at the elite level?

\section{Political participation and the internet}

Almost two decades of research on the effects of internet use on individual political and civic behavior have now been conducted with little sign of a consensus being reached. A number of studies have raised significant doubts about the mobilization potential of the internet, identifying instead a pattern of normalization akin to that noted above among elites whereby the already engaged are becoming even further empowered (Bimber, 1999, 2001, 2013; Scheufele \& Niesbet, 2002; Norris, 2003; Prior, 2005; Hindman, 2009). Contradictory evidence supporting the mobilization thesis has also been presented however. Internet use, measured simply as access (Tolbert \& McNeal, 2003; Kroh \& Neiss, 2012) or more specifically as searching for political information and engaging in online discussion (Hardy \& Scheufele, 2005; Esser \& de Vreese, 2007) has been shown to have positive influences on electoral participation. Reflecting this mixed set of results Boulianne (2009) in her meta-research on 39 studies of the Internet's impact on political engagement concluded that while overall the literature has pointed to a positive effect, it is only very small.

Following the findings of the elite level studies noted above, the arrival of web.2.0 has renewed speculation that the medium will promote a mobilization of less well engaged and resourced individuals into the mainstream and produce 'less socioeconomically stratified participation' (Jorba \& Bimber, 2012). This is supported by recent work by Smith, Schlozman, Verba and Brady (2009) and Smith (2013) who found that despite a persistent power of socio-demographic variables in explaining more traditional or 'converted' types of online participation in the U.S such as contacting or donating, that these gaps were less visible for political activities engaged in via social network sites. Other research has found that this newer type of social media based activism forms a distinctive type of 'e-expressive' participation (Rojas 
et al, 2005) and moreover that those drawn toward are generally younger, less interested and active in mainstream politics (Koc-Michalska \& Vedel, 2013).

Based on these findings we pose three questions about the French electorate and the effects of their internet use. Again the first two are primarily descriptive while the third integrates the findings to provide an answer to the question of normalization versus mobilization:

RQ4. What types of online political activity were French citizens engaging in during election campaigns, with what intensity and how much has this changed between 2007 and 2012?

RQ5. Which factors best explain users-citizens' level of online political activity in general and particularly with regard to new social media or web.2.0 tools?

RQ6: To what extent did the online campaigns of 2007 and 2012 indicate that new people were being drawn into the electoral process?

\section{DATA AND METHODOLOGY}

\section{Elite level analysis}

The first section of the analysis focuses on elite use of the web and social media in the two most recent French Presidential elections. Our data source were presidential candidates' websites during the 2007 and 2012 electoral cycle. We applied a content coding scheme derived from that developed by Gibson and Ward (2000) and commonly used for the description of electoral campaigns for elections of different levels or representatives' online presence (Ward \& Gibson, 2003; Conway \& Donard, 2004; Schweitzer, 2005, 2008, 2011; Foot \& Schneider, 2006; Vaccari, 2008; Lilleker \& Koc-Michalska 2013, 2014). We identified 27 basic features of sites that we treated as discrete variables and coded during both elections. In 2012 five additional features were identified as web.2.0 ${ }^{6}$. For the complete list of variables and codings

\footnotetext{
${ }^{6}$ The concept of the Web 2.0 is not fully conceptualized, however we follow Lilleker and Jackson (2011) in underlying the role of interactivity and resource generation, simplicity of content creation and non-hierarchical relations among the participants of communication.
} 
see Appendix Table 1. Features were seen as falling into one of four types of communication information provision (IP); interaction and engagement (I\&E), technological functionality (FT) and web.2.0 performance. While not exhaustive in terms of measuring site content and design they capture key aspects of campaign communication in terms of what the party or candidate thinks is important to tell the voters, how open they are to feedback and wider dialogue with the electorate and how conveniently or efficiently presented the material is. As such we can compare the web performance of smaller and larger party candidates on a range of different criteria and thus evaluate the extent to which normalization is taking hold.

To compare engagement in the four types of communication we standardized them by generating an average online performance score (AOP). This was derived by calculating an overall mean per type of communication from the maximum possible score in that strategy. This allows for straightforward comparisons of categories despite containing unequal numbers of features (Farmer \& Fender, 2005; Lilleker \& Koc-Michalska, 2013). The coding of the candidates' websites was performed during the week before the first round of Presidential elections between April 9 and 19, 2007 and April 12 and 22, 2012. While comparison between candidate sites in 2007 is fairly straightforward, comparison between 2007 and 2012 results is problematic. The online environment is constantly changing and new features and functionalities arriving. One has to face a choice between using consistent measures and sacrificing the ability to update to incorporate important new technological innovations, or adapting measures but then losing over-time reliability in one's indicators. We adopt a middle ground here in that we develop two indices. One is comparative and uses the same measures across the two elections. The other is specific to 2012 and measures candidates' web.2.0 performance This allows us to test for normalization in a longitudinal sense i.e. we can compare the performance of candidates from different parties over time and also the extent to which smaller or larger parties were expanding and improving the basic content of their web campaigns. We can also compare normalization in their web.2.0 use and whether it appears to be giving the edge to minor or major parties. 


\section{Mass-level Analysis}

The second part of the paper examines the question of normalization or mobilization at the citizen level and uses data from two pre-election online surveys conducted by Computer Assisted Web Interview (CAWI) on 16-29 January 2007 and 22-29 March 2012 on a representative ${ }^{7}$ sample of French Internet users. We do so using Poisson regression analysis technique that examine the effects of various drivers of participation on French citizens online engagement with the 2007 and 2012 elections. The surveys were cross-sectional and sample sizes differed. The $\mathrm{N}$ in 2007 was 1004, and in 2012 it was 2630. Both surveys were run before the first wave of presidential elections and were specifically designed to measures online political activities, usage of different information sources and electoral behavior ${ }^{8}$. Although they are not panel surveys, the data from the 2007 and 2012 surveys allow for meaningful comparison of online political behavior among French citizens over time. In particular we can compare the overall levels of online engagement in each election and the drivers of this behavior. As with the analysis of elite behavior described above we can examine this with some consistent indicators of basic or traditional political web use across time and specifically with regard to social media in 2012. This means that we can look both at whether normalization is increasing or reducing in terms of the types of people participating in online politics. We can also look and see whether the arrival of web.2.0 technology is helping to mobilize new people into politics.

Dependent Variables (see Appendix Table 2 for full details of question wording): The dependent variable is online political engagement and it is measured in two ways: (1) an additive index measuring a range of traditional online political actions which we label 'e-engagement' that is calculated for 2007 and 2012; and (2) an additive index of web.2.0 online political actions that we term 'e2- engagement' and measure

\footnotetext{
${ }^{7}$ Respondents are selected using a quota method (by sex, gender, education and region) in order to provide the representative sample of French Internet users (according to official measurements provided by Centre de Recherche pour l'étude et l'observation des conditions de vie, CREDOC. www.credoc.fr)

${ }^{8}$ CEVIPOF, Sciences-Po Paris is a research center specializing in French electoral studies (similar to ANES in the U.S. or BES in the UK) since 1960. The Center manages the surveys during different electoral periods (presidential, legislative, European or regional) on panel or cross-sectional samples representative for the French society. A vast part of this research concentrates on the relationships between political electoral behavior and the role of the media, offline and online campaigning (Mediapolis project).
} 
only in 2012. The first e-engagement index consisted of seven activities and scores ranged from zero to seven - the political activities included are shown in Table 3. (In 2007 52.2\% of respondents declared performing at least one activity (mean $\mathrm{M}=1.46 ; \mathrm{SD}=1.8$; Cronbach's $\alpha=.782$ ). Similarly, in $201252.3 \%$ declared at least one activity $(\mathrm{M}=1.41 ; \mathrm{SD}=1.8$; Cronbach's $\alpha=.809)$. The e2-engagement index range from zero to four and included political activities undertaken on social network platforms such as Facebook and Twitter. A brief examination of the frequencies revealed that $16.6 \%$ of respondents performed at least one of them $\left(\mathrm{M}=.25 ; \mathrm{SD}=.65\right.$; Cronbach's $\left.\alpha=.624^{9}\right)$.

In using two indices we are making a distinction between conventional types of online political engagement and more recently developed socially interactive forms. The idea that e-participation is multidimensional is one that has been gaining increasing theoretical and empirical support in the literature (Saglie \& Vabo, 2009; Rojas et al. 2009). Hoffman (2012) for example has argued that online engagement is two dimensional, constituting both participation and communication. Studies that can examine this more nuanced approach, however, are quite rare since they require a rich data source with multiple indicators of online political activities ${ }^{10}$. Most studies to date have through necessity relied on a limited number of individual measures of online engagement such as e-petition or e-contacting (Anduiza et al., 2010) or constructed a uni-dimensional index that adds these actions together (Best \& Krueger, 2005; Gibson \& Cantijoch, 2011; Gibson et al., 2010). As with our elite study in this analysis we adopt a middle ground in that we use two aggregated indices rather than individual measures. While one loses some of the plurality of the online experience through these aggregated measures they do capture a more general propensity to engage in online politics and smooth out any possible anomalies or spikes in activity caused by external 'shocks' such as a high profile online petition. Because our dependent

\footnotetext{
${ }^{9}$ The scale's Cronbach's $\alpha$ does not fulfill the standard reliability level (.7). The Cronbach $\alpha$ is very sensitive to 'the scale length' (Briggs \& Cheek 1986, p. 115). However as the indices are not a result of the statistical analysis (e.g. factor analysis) but rather an outcome of a theoretical assumptions based on the previous studies we decided to keep the indices regardless the sometimes weak internal consistency statistics.

${ }^{10}$ Hoffman (2012, p.223) enumerates twenty-seven different online political activities in PEW studies.
} 
variables are counts and not likely to follow a linear distribution we examine them using a Poisson regression models (Wooldridge, 2001).

Independent Variables: A range of key drivers of political engagement in general and online engagement more specifically are included as independent variables. These include measures of socio-demographic status that capture individuals' resources and capacity to participate (Verba et al., 1995; Anduiza et al., 2010) such as gender, age, education, income and class (for full details see Appendix, Table 2). In addition a range of political attitudes linked to a propensity to participate in politics (Chiche \& Haegel 2002; Belanger et al. 2012) are included such as political interest (Wolfinger \& Rosenstone 1980; Nie et al., 1996; Bréchon, 2006 ), whether one discusses politics (Mayer 2010), satisfaction with democracy (Kenski \& Stroud 2006; Wang 2007)., party proximity and ideological identification (Campbell et al. 1960; Vassallo, 2010).

We add a number control for individuals' media exposure including their exposure to other mainstream media, i.e. print, television, online and radio information sources ${ }^{11}$. We also measure their online experience through a combination of variables that measure the frequency and longitude of the Internet experience. This involved a three part categorization of individuals as historical, recent or new Internet users based on whether they had used the Internet for more than seven years and twelve years respectively in 2007 and 2012, from five to seven years, and less than five and seven years. The categories were then further split based on whether an individual used the Internet frequently i.e. more than one time per day in each of the three conditions. The variables were combined to create a category of Frequent Historical users (FH), Frequent Recent users (FR) and Frequent New users (FN). A further fourth category of Sporadic users was then created that included those individuals that used the Internet less often than once per day, regardless of when they began using the medium. According to these categories the distribution of experience in French internet users in 2007 was FH 27\%, FR 22\%, FN 28\%

\footnotetext{
${ }^{11}$ In France, television still keeps a strong place as the first source of political information, however other traditional media (print press and radio) are losing their audience mostly to the Internet (for more details on this change please see Table 2 in the Appendix).
} 
and Sporadic 23\%; in 2012 FH 37\%, FR 21\%, FN 29\% and Sporadic 13\%. It is clear then that there has been a drop in the number of sporadic users and those with longer experience online are using it even more frequently.

Finally, we have a control for traditional political engagement in the 2012 survey but this was not available in 2007. This is a combined measure of whether one had engaged in any of the conventional offline political activities (for their index, please see Appendix, table 2) or party activity (volunteering for a party or donating to a party). At least $70 \%$ of respondents performed at least one of the conventional political actions and less than $10 \%$ participated in party's activity.

\section{THE INTERNET DURING 2007 AND 2012 PRESIDENTIAL CAMPAIGNS}

\section{How French candidates used the web}

The 2007 Presidential election campaign was the first in France to witness an incorporation of a visible online presence within the communication strategies among all candidates. The campaigns consisted primarily of traditional websites, with both of the two main candidates creating additional platforms for their material. Right-wing candidate Nicolas Sarkozy offered Sarkozy TV which presented a series of videos setting out his plans and policies, while the Socialist candidate Ségolène Royal took a more interactive approach and developed a community of supporters through her Désirs d'avenir site. The 2012 campaign brought a substantial change in approach that was possibly stimulated by the 2008 success of Barack Obama's online campaign. Communication strategies widened with candidates extending their presence to picture and video sharing sites, blogs and social network platforms. Websites, but most of all social media platforms became lively hubs of information and discussion. The more vertical nature of the 
communication in 2007 (Royal's efforts notwithstanding) ${ }^{12}$ changed into a horizontal many-to-many communication in 2012.

This evolution was primarily due to a campaign strategy that aimed at visibility within the social media. In the month before the first round of voting all candidates posted around 6,400 Tweets, 1,250 posts on Facebook and gathered 720,000 followers on Twitter and 910,000 likes on Facebook who produced almost 600,000 comments. While this was quite small in comparison to the efforts of the two main U.S. candidates ${ }^{13}$ (Bimber, 2012) their social media popularity in terms of number of Twitter followers and Facebook likes was proportional ${ }^{14}$ to the vote they eventually received (for Twitter, the correlation with the votes gained is $r=.914$, while for Facebook this is $r=.687$ ) (see also Tumasjan et al., 2010; Ceron et al. 2013). By platform there were some differences in that François Hollande performed best on Twitter and Nicolas Sarkozy on Facebook. What is interesting, however, is that when one adjusts the Facebook supporter figures by the interactivity and communication exchange performed by the candidates strictly one month before the election day, it was Jean-Luc Mélenchon and Marine LePen who reached the highest level of performance ${ }^{15}$ relatively to the number of the comments and likes they received back (Koc-Michalska \& Lilleker, 2014).

Growth in the importance of online communication from 2007 to 2012 for Presidential candidates is also evident from the campaign spending of the candidates. According to figures obtained from the

\footnotetext{
${ }^{12}$ With the exception of the Ségolène Royal's Desirs d'avenir website with 135ths comments during a few months of existance (Bousquet 2009)

${ }^{13}$ Barack Obama gathered 22M Twitter followers and 33M Facebook supporters, Mitt Romney gathered 1.7M Twitter followers and 12M Facebook supporters. The difference of Facebook and Twitter communities in both countries is also significant. In US there were $166 \mathrm{M}$ of Facebook users at the end of 2012 while in France it was 25.6M (http://www.internetworldstats.com). Similar disproportion existed in 2012 for Twitter, with 7.3M user profiles in France and more than 140M in US (www.semiocast.com) (accessed 29.10.2013)

${ }^{14}$ The number of supporters on social network profiles varied in the same proportion as the number of votes gained by the candidates in an election. This may support the normalization thesis as more important candidates gathered larger supporter groups.

${ }^{15}$ We use here a Relative Interactivity Index (weighted number of posts by candidate and comments by her/his visitors per general size of the community) (for more details please see Koc-Michalska \& Lilleker, 2014).
} 
National Commission for Campaign Accounts and Political Financing ${ }^{16}$ in 2002 the average spending on the internet campaign of all candidates was only $2 \%$ of the overall campaign expenditure, by 2007 this had increased to $4 \%$ and by 2012 to $5 \%$. That growth was not equally distributed among all political actors as Table 1 shows.

Table 1 about here

The table compares the expenditure of candidates from the same party across the two elections. We see that half increased their online spending both in real numbers and as a share of total campaign expenditure. The greatest increase took place among extreme -right and extreme -left candidates. Front National representative Marine LePen increased her expenditure on web campaigning from $0.3 \%$ in 2007 to $3 \%$ in 2012 while the left-wing Jean-Luc Mélenchon (FdG) raised the amount spent from 2.2\% to 7.5\%. The winning candidate, François Hollande, however, actually decreased his online expenses in comparison to the socialist candidate of the 2007 elections (from 866,000 Euro in 2007 to 546,000 Euro in 2012). Part of this reduction may be because he relied more heavily on existing resources such as his own website, website of the Socialist Party (PS) as well as the volunteer hub La Coopol www.lacoopol.fr. Perhaps most importantly, however, he did not invest in the personal social network platform launched by Ségolène Royal in 2007 (www.desirsdavenir.org) but used free services such as Facebook and most of all Twitter. By contrast Nicolas Sarkozy, the incumbent president, doubled his online spending and ran the most expensive online campaign ever (spending over $€ 1.3$ million). The 'third player' of the 2007 campaign, Francois Bayrou representing Union for French Democracy (MoDem) also slightly increased the share dedicated to the online campaign although he lowered his overall campaign expenses in 2012. Given the quite substantial difference in the investment made by the two main candidates in their online campaigns and the final election results, it would appear on face value that the web did not decisively

\footnotetext{
${ }^{16}$ Commission Nationale Des Comptes De Campagne Et Des Financements Politiques www.cncefp.fr. There are evidences however that the official spending may not fully cover the total spending on campaigns (Greffet 2013) as some parts of the structural budget could have been spend before the official campaign (e.g. equipment, advisors etc.), however for the comparative reasons we use official budgets presented to the Commission by all candidates.
} 
affect their fate. However, that said it is of course also possible that Hollande was simply more strategic in this deployment of the technology than Sarkozy and targeted his efforts more efficiently.

Content Analysis: We explore this question of deployment in greater depth below. In particular we compare the strategies of the candidates in their electoral campaigns in 2007 and 2012 regard to our three dimensions of interest - Information Provision, Interaction and Engagement and Technological Functionality. So we first address RQ1 and compare the candidates websites on our three indices across time. We then examine RQ2 their use of web.2.0. Table 2 reports the key results on each index for all candidates' based on their personal homepages.

Table 2 about here

The results show that in both years campaigns were focused more on information than interaction. During the 2007 elections $42 \%$ of candidates offered the possibility to comment and $25 \%$ to debate on their own website. One exception to this was Ségolène Royal who developed a purpose-built highly sophisticated social networking platform. By 2012 interaction via homepages was even more limited with 30\% of candidates permitting comments but none provided space for web-based debate. Despite this decreasing enthusiasm for debate, there was a push by some candidates to create some kind of community portal rather than offer more personalized home pages. Sarkozy created a supporter site based on his campaign slogan - la France forte - and Jean-Luc Mélenchon (supported by the coalition of the left wing parties and associations) set up placeaupeople2012.fr (on the side of his well-established blog). The fringe left wing candidates Poutou (NPA) and Arthaud (LO) both appeared to spend very little on online campaigning and did not appear to have a clear online strategy other than maintaining a simple presence. The candidate of the extreme-right Marine Le Pen definitely put more emphasis on online performance than her forerunner in 2007. She was extensively using her website to promote information and her ideas, and employed social media platforms for debates among critics and supporters (apparently without strong moderation of the comments). During both campaigns generally all candidates performed better on 
information provision than on interaction and engagement indices -- both scores have decreased in 2012. The exception is technological development of the websites, element of campaign professionalization, which has slightly increased in 2012 (.700 in comparison to .667 in 2007), and this increase is mostly due to a visible change within the fringe candidates' performance, who as the only group improved in this category in time.

In 2007 there were three leaders in information provision gaining the same score of .796: N. Sarkozy (right), F. Bayrou (center) and M. Buffet (extreme left). In 2012 only M. LePen (extreme right) achieved that level. The lowest performance in both categories in 2007 had A. Laguiller (extreme left)(IP .308 and I\&E .200). Her 2012 successor N. Arthaud did not manage to increase importantly that score (IP .308 and I\&P .400). Both main candidates performed worse in 2012 than in 2007 on both indexes. It is especially unexpected for N. Sarkozy who almost doubled his online expenses (see Table 1).

In 2007 it was Nicolas Sarkozy and Ségolène Royal that ran the most sophisticated campaign. The former used an innovative movie-based website and the latter created her own social network platform for internal and external debating (Désirs d'avenir). Francois Bayrou created probably the most interactive website-based platform allowing for comments and online debating. In 2012 there was no definite leader, as most of the candidates had a similar website architecture, with pop-ups (mostly to collect e-mail addresses), interestingly arranged information about local campaigning and contacts (visualized with the googlemap tool), offering the possibility to volunteer offline and online (a 'kit for volunteers'), links to social media platforms and the opportunity to share, print and download page content.

While the fall in interactivity on candidates' personal homepages may reflect an increasing reluctance of candidates to engage in dialogue with French voters, it is likely also to be related to the increased use of web.2.0 tools. By 2012 as Table 3 shows, interactivity were more commonly found on social media platforms. Table 3 reports the results for each candidate on AOP of the web.2.0 index. 
Table 3 about here...

The table reveals that social media platforms had basically become the 'must have' element of the campaign with $90 \%$ of candidates having a Twitter account and $80 \%$ maintaining a profile on Facebook. Sixty percent shared videos on Youtube or/and Dailymotion and all regularly updated the content they provided. The extreme left candidate N. Arthaud ignored social media altogether. She did not have a Facebook profile, and her Twitter account had only one entry. Neither interaction nor engagement were offered on her website. Without surprise, F. Bayrou had the highest score on the web.2.0 index replicating his interactive success from 2007. He moved the place of interaction from his proper website to social networks platforms, however. The same score was obtained by N. Dupont-Aignan (right, a long standing politician) that made his debut in the Presidential election.

If we look at the AOP scores we start to draw some conclusions regarding RQ3 and the issue of whether a normalization in web campaigning is occurring across major, minor and fringe parties. In 2007 major candidates were outperforming the minor and fringe candidates according to all three of the measures we applied. However, by 2012 this was no longer the case. In 2007 the AOP difference for Information Provision was (.142) between the major and minor candidates, while in 2012 it was reduced to only (.019). An even stronger result can be found in the AOP difference in Interaction and Engagement provision. In 2007 major parties outperformed the minor ones by (.417); in 2012 it was the minor parties who performed better by (.075) points. The contrast between the two years becomes even more pronounced when one looks at web.2.0 performance in 2012 which is broadly equivalent among major and minor candidates. Fringe candidates, however, do lag behind their counterparts regardless of the category and period. Aside from the role of party status here, it is clear that ideological outlook played an important if inconsistent role in both years. While the left tended to perform better in the 2007 election, the situation is reversed in 2012 with right wing candidates performing best. One may argue that this is not an ideological but rather an incumbent-challenger division. However this is a hypothesis that needs further investigation. 
Finally we examine the resource based hypothesis of normalization vs. mobilization effect by correlating the financial resources dedicated to campaign (Table 1) and the level of the online performance of the candidates (AOP, Table 2 and 3) separately for each year. The results confirm a shift towards mobilization thesis in 2012. In 2007 correlations are statistically significant for all AOP (IP: $r=.603$ $(\mathrm{p}=.038) ; \mathrm{I} \& \mathrm{E}: \mathrm{r}=.588(\mathrm{p}=.044) ; \mathrm{TF}: \mathrm{r}=.743(\mathrm{p}=.006))$ in 2012 none of the correlations go beyond $\mathrm{r}=.3$ and none is statistically significant. This may indicate that while in 2007 the financial resource of the candidates played an important role in building their online presence and candidates with better financial status were outperforming their smaller counterparts, then five years later it was no longer the case.

Overall, therefore, in the results of our elite level analysis would appear to raise something of a challenge to the normalization thesis in that candidates for the minor parties now offer content that is as rich as that offered by those from major parties. That said, the mobilization thesis cannot be fully confirmed as fringe candidates still lag behind those with better resources. In addition these findings are limited to a national and very high profile race. Results for the local candidates of minor parties in parliamentary elections may present a rather different and less competitive story.

\section{French Internet users and their engagement in the campaign}

We move now to examine our next set of research questions about the normalization and mobilization effects of internet use in the 2007 and 2012 Presidential elections from the individual voters' perspective. By 2012 French Internet users constituted $83 \%$ of the French society. This move to near universal access was fast in that in 1998 only $6 \%$ had online access. The increase was particularly concentrated around two time points. First in 2000 the share of French users increased by 12 percentage points, and in 2007 by 19 percentage points (for the details please see Table 3 in Appendix). Table 4 deals with RQ4 and presents some basic frequencies of the various types of activity we measured over time using our e-engagement measures. The results show some interesting trends in that we see an increase in some actions and a decrease in others. So the French are less likely to read political blogs, transfer political information or visit candidates' and parties' websites in 2012, but are more eager to watch political videos, participate in 
discussions and search for the information about the election online. They are especially interested in humorous content. Turning to the web.2.0 or e2-engagement which we measured in 2012 only, almost 17 percent or one in five of those internet users sampled performed any e2-engagement activity. Much of this activity involved receiving campaign information via social network profiles (14\%) or Twitter (4\%) with a smaller proportion actively posting political information on their social network profiles (6\%) or Twitter $(2 \%)$

Table 4. about here

If we then examine these findings with RQ5 in mind, i.e. the factors driving this use we can see that some changes occur across the two election cycles. Table 5 reports the Poisson regression models predicting the traditional e-engagement (a comparison between 2007 and 2012) and e2-engagement (only for 2012 but with the same explanatory model); additionally it shows the 2012 e-participation and e2engagement with the extended model controlling for offline political participation and party activity. The results show a number of important changes over time in relation to our research questions. A first key point is the role and change in the demographic variables' effects over time in relation to predicting eengagement. In 2007 gender, income and the social group identification were all significant predictors of online activity although with the exception of the lower activity among women the impact was not in the direction anticipated by normalization. Interestingly it was lower class blue-collar workers and those who were less well-off were more likely to participate online in 2007. This may be a specific effect of the growth of the Internet users population. We would speculate that it could have been the group of blue collar workers and those worst-off who could have joined the online community during its last important growth (by 19 percentage points from 2006) most probably due to the easier technological access to Internet connections (through broadband and wifi) and lowered costs of such connection.

By 2012 in contrast we find that demographic effects have all but disappeared. Not surprisingly attitudinal variables such as interest in politics, having a partisan identification and a propensity to discuss 
politics exert a positive effect on political engagement cross-time and cross indexes. However, satisfaction with democracy is a negative predictor in 2012 , so those who were less pleased with how the French political system performed were more likely to be looking for political information online. Party identification is a strong predictor for traditional e-engagement (in contrary to e2-engagement, see below). Those leaning towards any party are more willing to engage than those who cannot place themselves within any party system programs. On the contrary to the expectations based on the fact that French Internet users tend to be more left-wing oriented (see discussion above), political and ideological views have no significant effect on online political behaviour. The effects of media exposure are somewhat predictable in that a preference for the Internet as the first source of political information is a positive predictor of all types of online engagement in both years. However, the effect of reading newspapers is interesting in that it has no effect in 2007 but by 2012 becomes an important predictor of online engagement. Perhaps this effect is significant due to the presence of online versions of the print press (which is not considered by a part of respondents as an 'internet source'). This may be also an indicative of the growing importance of 'pure players', popular media outlets present only online (mediapart.fr, huffingtonpost.fr, rue89.fr) in delivering high quality information and investigative journalism covering political scandals. It is possible that the general trend of information consumption may have influenced peoples' predisposition for performing other online activities than searching for news. Or, on the contrary, there is a pure effect of print version reading of the national and regional press, which gathers a specific audience with a high level of political interest and engagement. Finally, the results show that as one would expect, our variable capturing individuals' levels of internet experience and familiarity is significant, those using the Internet for longer and most frequently are in general more likely to perform online political activities. Although the effect of this prior experience seems to decline over time.

For e2-engagement, a similar and even more notable pattern emerges in regard to demographic predictors as for e-engagement in 2012. Age is the strongest determinant and its effect runs in a negative 
direction, younger people tend to engage more in web.2.0 based political activities. Attitudinally a similar pattern emerges in that interest in politics and discussion are positive but dissatisfaction with democracy appears to be an even stronger driver for e2-engagement. Partisan identification, however, is not significant for e2-engagement, suggesting that political participation via social network sites may be drawing in those who feel less attached to the traditional, institutional offline political sphere and who are looking for new forms of political expression, .

In the final two columns of Table 5, we present the analysis with additional control variables that were available only for 2012. This includes level of individuals' offline political engagement and party involvement. The addition of these variables points to some interesting relationships between offline and online forms of engagement. While offline political engagement is strongly correlated with traditional eengagement, however it does not predict e2-engagment. More surprisingly, however, is that the latter is strongly linked to undertaking voluntary work for a party and donating money to parties. This finding is intriguing in that it suggests that those political active in online social networks are also particularly active in working for parties. So as well as attracting younger individuals, habitually not associated with politics.

Table 5 around here please

To check for the robustness of our findings on traditional online political e-engagement (Table 5) we have also run pooled (both data from 2007 and 2012 gathered in one data set) Poisson regression ${ }^{17}$. They confirmed a diminishing impact of structural-demographical variables in time (not statistically significant). Regardless the analytical method used political attitudes and ideology variables remained statistically significant with strong coefficients: those individuals who are more interested in politics and/or in electoral campaigns, have the least trust in the functioning of the French democracy, with a propensity for political discussion and deep-rooted party proximity are more likely to engage in traditional online political activities.

\footnotetext{
${ }^{17}$ The result of the pooled Poisson regression is not shown here (as giving similar results as in Table 5) but is available upon request from authors.
} 
Overall, therefore our results do confirm a shift in the drivers for online engagement in the election campaign with a move toward greater diversity in the participant pool in terms of their political experience and background. Essentially in answer to RQ6 there is evidence of a mobilization effect, particularly for the newer social media or 'e2' types of activity.

\section{Supply and demand}

When analyzing the uses of the internet during electoral campaigns, it is important to capture both the supply and the demand sides. How citizens use the internet for political purpose depends in part of the online strategies implemented by candidates. Reciprocally, parties and candidates try to adapt their online strategies to users' behavior and demands.

However, the attempt to compile together the two sides of the communication process - supply and demand side - is extremely difficult and has important limitations. The most important obstacle is probably the methodological difficulty to achieve similar level of accuracy in both approaches. The content analysis phase does not superimpose any limitations of features to examine; on the contrary survey research is restrained by the numbers of questions and items to be enumerated. Thus the juxtaposition of the two sides would always have a limitation and lack the exact match.

Our study indicates that candidates in Presidential elections tend to fulfill (maybe even excessively) the expectations of their audiences, their dominant web strategy is to supply the information (IP strategy, Table 2) which match with the most often performed activity of the Internet users, as one third of them search more profound information about elections (Table 3). In 2012 among those who searched for political information about elections $42 \%$ also visited candidates' websites and $32 \%$ got such information through social network (however we did not controlled for the source). Candidates seem to quite well read the expectations among audiences and strategically deliver the most sought features. Fairly popular among the Internet users online video watching (22\% in 2012) is well served by the candidates (9 out of 
10 propose them on websites and 6 on video sharing sites), on the contrary less popular active participation (debating online on chat or forums, 7\%) is delivered by minority of candidates (3 out of 10). Similarly the performance of candidates on social network platforms is rather intense, with firm majority present and constantly updating their Facebook and Twitter account. However only one fifth of the French Internet users performed political activities - passive or active - on social networks. The relation seems unbalanced with high performance of the political actors and rather weak possible response from the audience. The social network presence is rather a 'must be' for the political actors and the occasion to reach special group of citizens (younger, those less participating in more conventional types of political engagement and somehow partisan, see Table 5) than the opportunity to meet a vast majority of the society.

\section{CONCLUSIONS}

Presidential elections are important political events in France. They attract media attention, intensify communication efforts of candidates and bring the vast majority of citizens to the ballot box. Until 2007 campaign communication by candidates took place largely through television coverage, conventions, and town-hall meetings. In 2007 the internet became an additional element of the campaign strategy. By 2012 it was integral and took on a multi-platform presence.

Candidates have come to see the Internet as an important and highly cost-efficient tool of campaigning indeed some candidates actually reduced spending on their online efforts in 2012 compared with 2007. This move away from a resource-intensive model of campaigning suggests a challenge to idea of the normalization of web campaigning. Our closer analysis of actual content provision across the two elections supported this trend. Measured through their personal home pages it is clear the online performance of the candidates is remaining fairly constant for the major candidates with no great leaps in content and functionality between the two elections. Candidates from minor and fringe parties are 
improving their presence to the point where the former in fact outperformed their better resourced counterparts. The 2012 election was not devoid of innovation however, with candidates expanding their portfolio of campaign tools to include social network platforms. Here again in defiance of the normalization thesis, the minor parties performed as well as the major players.

While we assessed the impact of the Internet on levels of inter-party competition through an analysis of the quality of candidates' web presence, it is clear from the testimonies of strategists responsible ${ }^{18}$ for the 2012 web campaigns of the candidates that their value does not lie simply in their presentational features and the variety of content they contain. Sites are a core channel to reach sympathizers and supporters and turn them into active militants. For fringe parties in particular, Internet communication seems to be vital as a means for by-passing traditional media and reaching their support base directly or indirectly through the two-step flow of communication. Thus, although they performed less well than their bigger rivals according to the measures used here, we need to also bear in mind the wider 'return' on investment in terms of the web campaign's organizational and tactical value for smaller players.

At the mass level, our study also presented a challenge to the idea of normalization. Internet use is widespread and the medium has become an important source of political information. Education and other socio-economic factors are largely irrelevant as drivers to this type of activity. And while it is the case that those who are more interested in politics and closer to political parties are more likely to seek out information online, the medium also attracts those with less of a stake in the system. In particular the 2012 electoral cycle witnessed the birth of new online public sphere -social networking platforms - with an audience that is definitely younger, does not feel well served by the current democratic system, and are not participating in offline conventional political activities. For such individuals, entry into politics might not take place through the established modes of offline activities or even more regular types of website

\footnotetext{
${ }^{18}$ This paragraph is based on the in-depth interviews performed by Pierre-Emmanuel Guigo in the aftermath of the 2012 campaign with the campaign strategists: JF. Martins (F. Bayrou), JF. Jalkh and D. Rachline (M. LePen), O. Faure (F. Hollande), B. Millot (UMP), B. Buisson (J. Cheminade) within a project 'Les gourous de la com', Sciences-Po, Paris.
} 
activities but through social network platforms - among them most popular Facebook or Twitter resending, posting or passively coming across political messages dispatched by political actors or by their friends.

Given the direction of travel of research on mobilization and normalization discussed earlier these findings are significant. Essentially our findings take one of the more high profile national online campaigns which one might argue can serve as a bell weather for future trends and shows that pessimism over the potential of the web to open up campaign communication and election engagement may be misplaced. In particular if we look beyond the idea that the web's power is to be judged primarily as a means of vote generation to one of organizational infrastructure and resource generation then it does seem that it has important redistribute qualities. This seems particularly true in relation to the use of social media and web.2.0 platforms. This redistribution or mobilization effect also seems to emerge at the citizen level with the typical gap in resources between participants and non-participants appearing to recede in the most recent election and particularly with regard to patterns of e2-engagement. The extent to which these findings can be generalized beyond the French case is of course subject to future empirical analysis. The results, however, do confirm those from Australia regarding the greater enthusiasm of Green candidates for social media online tools in recent campaigns. In terms of citizen involvement, again the idea that social media are mobilizing younger and less typically interested individuals in election campaigns is in line with recent findings from the UK and the U.S. As such the results provide at least some tentative support for the idea that while context matters, the latest generation of socially compatible communication technologies may be opening up a new opportunity for the less well resourced to become politically active in elections. 


\section{Literature}

Anduiza, E., Gallego, A., \& Cantijoch, M. (2010). Online Political Participation in Spain: The Impact of Traditional and Internet Resources. Journal of Information Technology \& Politics, 7(4), 356-368.

Anstead, N., \& Chadwick, A. (2008). The 2008 Digital Campaign in the United States: The Real Lessons for British Parties. Renewal: Journal of Labour Politics 16, 86-98.

Belanger, E., Cautrès, B., Foucault, M., Lewis-Beck, M., \& Nadeau, R. (2012). Le vote des Français de Mitterrand à Sarkozy. Paris: Presses de Sciences Po.

Bentivegna, S. (2006). Rethinking politics in the world of ICTs. European Journal of Communication, 21(3), 331-343.

Best, S., \& Krueger, B. (2005). Analyzing the representativeness of Internet political participation. Political Behavior, 27(2), 183-216.

Bimber, B. (1999). The Internet and citizen communication with government: does the medium matter?. Political Communication, 16, 409-428.

Bimber, B. (2001). Information and political engagement in America: The search for political effects of the Internet. Political Research Quarterly, 54(1), 53-67.

Bimber, B. (2012). Digital Media in the Obama Presidential Campaigns: Comparing 2008 and 2012.

Presentation given during Chasing the Digital Wave: International Lessons for the UK 2015 Election

Campaign, Hansard Society.

Bimber, B., \& Copeland, L. (2013). Digital media and traditional Political Participation Over Time in the U.S.. Journal of Informational Technology and Politics, 10, 125-137.

Bond, R., Fariss, C., Jones, J., Kramer, A., Marlow, C., Settle, J., \& Fowler J. (2012). A 61-millionperson experiment in social influence and political mobilization. Nature, 489, 13 September.

Boulianne, S. (2009). Does Internet Use Affect Engagement? A Meta-Analysis of Research. Political Communication, 26(2), $193-211$. 
Bousquet, F. (2009). Le net-campagne de 2007: entre mobilisation et participation. In P. Maarek (Ed.) $L a$ communication politique de la présidentielle de 2007. L'Harmattan, Paris.

Bréchon, P. (2006). Comportements et attitudes politiques. Grenoble: Presses universitaires de Grenoble.

Briggs, S. \& Cheek, J. (1986). The role of factor analysis in the development and evaluation of personality scales. Journal of Personality, 54(1), 106-143.

Campbell, A., Converse, P., Miller, W., \& Stokes, D.(1960). The American Voter. New York: Wiley

Carlson, T. \& Djupsund G. (2001). Old Wine in The New Bottle? The 1999 Finish Election Campaign on the Internet. Press/Politics 6(1), 68-87.

Carlson, T., \& Strandberg, K. (2008). Plus ça change, plus c'est la même chose? The evolution of Finnish web campaigning 1996-2004. In J. Strömbäck (Ed.), Communicating Politics: Political Communication in the Nordic Countries (pp 161-179), Göteborg: Nordicom,.

Ceron, A., Curini, L., Iacus, S. \& Porro, G. (2013). Every tweet counts? How sentiment analysis of social media can improve our knowledge of citizens' political preferences with an application to Italy and France. New Media \& Society April.

Chadwick, A. (2012). Recent Shifts in Relationship between the Internet and Democratic Engagement in Britain and United States Granularity, Information Exuberance, and Political Learning. In E. Anduiza, M. Jensen, \& L. Jorba (Eds.) Digital Media and Political Engagement Worldwide. A Comparative Study. Cambridge University Press.

Chiche, J. \& Haegel, F. (2002). Les connaissances politiques. In G. Grumberg, N. Mayer \& P. Sniderman (Eds.) La démocratie à l'épreuve. Une nouvelle conception de l'opinion des français. (pp. 273-292). Paris: Presses de Sciences-Po.

Coleman, S., \& Gøtze, J. (2001). Bowling Together: Online Public Engagement in Policy Deliberation. Hansard Society, London. 
Colombo, C., Galais, C., \& Gallego, A. (2012). Internet Use and Political Attitudes in Europe. In E. Anduiza, M. Jensen, \& L. Jorba (Eds.), Digital Media and Political Engagement Worldwide. A Comparative Study. Cambridge University Press.

Conway, M., \& Donard, D. (2004). An Evaluation of New Zealand Political Party Websites. available at http://informationr.net/ir/9-4/paper196.html (accessed 01.05.2013).

Druckman, J., Kifer, M., \& Parkin, M. (2010). Timeless strategy meets new medium: Going negative on congressional campaign web sites, 2002-2006. Political Communication, 21(1), 88-103.

Esser, F., \& de Vreese, C. (2007). Comparing Young Voters' Political Engagement in the United States and Europe. American Behavioral Scientist, 50.

Farmer, R., \& Fender, R. (2005). E-parties: democratic and republican state parties in 2000. Party Politics, 11, 47-58.

Foot, K., \& Schneider, S. (2006). Web Campaigning. Cambridge, MA: MIT Press.

Foot, K., Schneider, S., Kluver R, Xenos, M. \& Jankowski, N. (2007). Comparing web production practices across electoral web spheres. In R. Kluver, N. Jankowski, K. Foot, \& S. Schneider (Eds.) The Internet and National Elections: A Comparative Study of Web Campaigning, (pp. 243-260). London: Routledge.

Gibson, R., \& Cantijoch, M. (2011). Conceptualizing and measuring participation in the age of the internet: Is online political engagement really different to offline?. Paper presented at the Colloquium "Methodological Challenges in Participation Research", Cordoba, Spain, 4-5 November available at http://drupals.humanities.manchester.ac.uk/ipol/sites/default/files/newdocs/Cordoba_2011.pdf (accessed 01.05.2013).

Gibson, R., \& McAllister, I. (2014). Normalizing or Equalizing Party Competition? Assessing the impact of the web on election campaigning. Political Studies.

Gibson, R., \& Ward, S. (1998). U.K. Political Parties and the Internet. "Politics as Usual" in the New Media? Press/Politics 3(3), 14-38. 
Gibson, R., \& Ward, S. (2000). A Proposed Methodology for Measuring the Function and Effectiveness of Political Web-Sites. Social Science Computer Review, 18.

Gibson, R., Cantijoch, M., \& Ward, S. (2010). Another False Dawn? New Media and Citizen Participation in the 2010 UK General Election. Paper presented at the Elections Public Opinion and Parties Conference, University of Essex. September. Available at http://drupals.humanities.manchester.ac.uk/ipol/?q=node/6 01.05.2013 (accessed 01.05.2013).

Gibson, R., Margolis, M., Resnick, D., \& Ward, S. (2003). Election campaigning on the WWW in the USA and UK - a comparative analysis. Party Politics, 9(1), 47-75.

Greffet, F. (2013). New technique, new mobilizations? French parties in web 2.0 era. In P. Nixon, R. Rawal \& D. Mercea (Eds.) Politics and the Internet in Comparative Context: Views from the Cloud. Routledge.

Gueorguieva, V. (2007). Voters, MySpace, and YouTube: The Impact of Alternative Communication Channels on the 2006 Election Cycle and Beyond. Social Science Computer review (December).

Hamilton, A., \& Tolbert, C. (2012). Political Engagement and the Internet in the 2008 U.S. Presidential Elections: A Panel Survey. In E. Anduiza, M. Jensen, \& L. Jorba (Eds.) Digital Media and Political Engagement Worldwide. A Comparative Study. Cambridge University Press.

Hardy, B., \& Scheufele, D. (2005). Examining Differential Gains From Internet Use: Comparing the Moderating Role of Talk and Online Interactions. Journal of Communication, 55(1), 71-84.

Hindman, M. (2009). The Myth of Digital Democracy. Princeton, NJ: Princeton.

Hoffman, L. (2012). Participation or Communication? An Explication of Political Activity in the Impact of the Web on Election Campaigning. Journal of Information Technology and Politics, 9 (3).

Jorba, L., \& Bimber, B. (2012). The impact of the Digital Media on Citizenship from a Global Perspective. In E. Anduiza, M. Jensen, \& L. Jorba (Eds.) Digital Media and Political Engagement Worldwide. A Comparative Study. Cambridge University Press.

Kalnes, O. (2009). Norwegian Parties and Web 2.0. Journal of Information Technology \& Politics, 6(3). 
Kenski, K., \& Stroud, N. (2006). Connections Between Internet Use and Political Efficacy, Knowledge, and Participation. Journal of Broadcasting \& Electronic Media, 50(2), 173 -192.

Kluver, R., Jankowski, N., Foot, K., \& Schneider, S. (2007). The Internet and national elections. A comparative study of web campaigning. Routledge.

Koc-Michalska, K., \& Lilleker, D. (2013). MEPs online: Understanding communication strategies for remote representatives. In P. Nixon, R. Rawal \& D. Mercea (eds.) Politics and the Internet in Comparative Context: Views from the cloud. London: Routledge.

Koc-Michalska, K., \& Lilleker, D. (2014). Interagir avec les candidates: les stratégies interactives lors de l'élection présidentielle française de 2012. In P. Maarek (Ed.) Présidentielle 2012, une communication politique bien singulière (pp. 149-165), L'Harmattan, Paris.

Koc-Michalska, K., \& Vedel, T., (2013). Les pratiques informationnelles durant la campagne presidentielle. In P. Perrineau (ed.) Le vote normal. Les élections présidentielle et législatives d'avril-juin 2012. Paris, Presses de Sciences Po.

Kroh, M. \& Neiss, H. (2012). On the Causal Nature of the Relationship between Internet Access and Political Engagement: Evidence from German Panel Data. In E. Anduiza, M. Jensen, \& L. Jorba (Eds.) Digital Media and Political Engagement Worldwide. A Comparative Study. Cambridge University Press. Lilleker, D. \& Jackson, N. (2011). Elections 2.0: Comparing E-Campaigns in France, Germany, Great Britain and the United States. In J. Schweitzer \& A. Steffen, Das Internet im Wahlkampf, Analysen zur Bundestagswahl 2009. Wiesbaden: VS, 96-116.

Lilleker, D., \& Koc-Michalska, K. (2013). Online political communication strategies: MEPs erepresentation and self-representation. Journal of Information Technology and Politics, 10 (2).

Lilleker, D., \& Koc-Michalska, K. (2014). Online delivery and demand in France 2012 presidential election. In J. Bishop, A. Solo (Eds.) Politics and Policy in the Information Age. IGI (forthcoming). 
Lilleker, D., Koc-Michalska, K., Schweitzer, E., Jacunski, M., Nigel, J., \& Vedel, T. (2011). Informing, Engaging, Mobilising or Interacting: searching for a European model of web campaigning. European Journal of Communication, 26.

Margolis, M., \& Resnick, D. (2000). Politics as usual: The cyberspace “revolution.” Thousand Oaks, CA: Sage Publications.

Margolis, M., Resnik, D., \& Ch., Tu (1997). Campaiging on the Internet. Parties and Candidates on the World Wide Web in the 1996 Primary Season. Press/Politics 2(1): 59-78.

Mayer N. (2010). Sociologie des comportements politiques. Paris: Armand Colin.

Morozov, E. (2013). The Net Delusion: The Dark Side of Internet Freedom. New York: PublicAffairs.

Nam, T., \& Stromer-Galley, J. (2012). The Democratic Divide in the 2008 U.S. Presidential Election. Journal of Information Technology \& Politics, 9(2), 133-149.

Nie, N., Junn, J., \& Stehlik-Barry, K. (1996). Education and Democraticship in America. Chicago: The University of Chicago Press.

Norris, P. (2003). Preaching to the Converted? Pluralism, Participation and Party Websites. Party Politics, 9(1), 21-45.

Norris, P., \& Curtice, J. (2008). Getting the Message Out: A Two-Step Model of the Role of the Internet in Campaign Communication Flows During the 2005 British General Election. Journal of Information Technology \& Politics, 4(4), 3-13.

Prior, M. (2005). News vs. Entertainment: How Increasing Media Choice Widens Gaps in Political Knowledge. American Journal of Political Science, 49(3), 577-592.

Resnick, D. (1998). Politics on the internet: The normalization of cyberspace. In: C. Toulouse \& T. Luke (eds.) The Politics of Cyberspace. New York: Routledge, 48-68.

Rojas, H., Shah, D., Cho, J., Schmierbach, M., Keum, H., \& Gil de Zuniga, H. (2005). Media Dialogue: Perceiving and addressing community problems. Mass Communication \& Society, 8. 
Saglie, J., \& Vabo, S. (2009). Size and e-Democracy: Online Participation in Norwegian Local Politics. Scandinavian Political Studies, 32(4).

Scheufele, D., \& Nisbet, M. (2002). Being a citizen online - New opportunities and dead ends. Harvard International Journal of Press-Politics, 7, 55-7.

Schweitzer, E. (2005). Election Campaigning Online: German Party Websites in the 2002 National Elections. European Journal of Communication, 20(3), 327-51.

Schweitzer, E. (2008). Innovation or Normalization in E-Campaigning?: A Longitudinal Content and Structural Analysis of German Party Websites in the 2002 and 2005 National Elections. European Journal of Communication, 23.

Schweitzer, E. (2011). Normalization 2.0: A longitudinal analysis of German online campaigns in 9 -the national elections 2002. European Journal of Communication, 26.

Smith, A. (2013). Civic Engagement in the Digital Age. Pew Internet \& American Life Project, available at http://pewinternet.org/Reports/2013/Civic-Engagement.aspx (accessed 01.05.2013).

Smith, A., Schlozman, K., Verba, S., \& Brady, H. (2009). The Internet and Civic Engagement, Pew Internet \& American Life Project, available at http://www.pewinternet.org/Reports/2009/15--TheInternet-and-Civic-Engagement.aspx (accessed 01.05.2013).

Strandberg, K. (2014). A Social Media Revolution or Juts a Case of History Repeating Itself? - The Use of Social Media in the 2011 Finnish Parliamentary Elections. New Media \& Society (forthcoming).

Tkach-Kawasaki, L. M. (2003). Clicking for votes: assessing Japanese political campaigns on the web. In K.C. Ho, R. Kluver, \& K.C. Yang (Eds.), Asia.com: Asia encounters the Internet. (pp. 159-174). London: Routledge Curzon.

Tolbert, C., \& McNeal, R. (2003). Unraveling the effects of the internet on political participation?. Political Research Quarterly, 56 (2).

Tumasjan, A., Sprenger, T., Sandner, P., \& Welpe, I. (2010). Predicting Elections with Twitter: What 140 Characters Reveal about Political Sentiment. Proceedings of the Fourth International AAAI Conference 
on Weblogs and Social Media, available at http://www.aaai.org/ocs/index.php/ICWSM/ICWSM10/paper/viewFile/1441/1852 (accessed 01.05.2013). Vaccari, C. (2008). Surfing to the Elysee: The Internet in the 2007 French Elections. French Politics, 6, 1-22.

Vaccari, C. (2013). Digital Politics in Western Democracies: A Comparative Study. Johns Hopkins University Press.

Vassallo, F. (2010). France, Social Capital and Political Activism. London: Palgrave MacMillan.

Vedel, T., \& Cann, Y. (2008). Internet. Une communication électorale de rupture?. In P. Perrineau, Le vote de rupture, Press de Sciences-Po, Paris.

Verba, S., Schlozman, K., \& Brady, H. (1995). Voice and equality: Civic voluntarism in American politics. Cambridge, MA: Harvard University Press.

Vergeer, M., Hermans, L., \& Cunha C. (2013a). Web campaigning in the 2009 European Parliament elections: A cross-national comparative analysis. New Media \& Society 15, 128-148.

Vergeer, M., Hermans, L., \& Sams, S. (2013b). Online social networks and micro-blogging in political campaigning: The exploration of a new campaign tool and a new campaign style. Party Politics, 19.

Wang, S. (2007). Political use of the Internet, political attitudes and political participation. Asian Journal of Communication, 17.

Ward, S., \& Gibson, R. (2003). Online and On Message? Candidates Websites in the 2001 General Election. British Journal of Politics and International Relations. 5(2), 188-205.

Wolfinger, R., \& Rosenstone, S. (1980). Who Votes? New Haven and London: Yale University Press

Wooldridge J. M. (2001). Econometric analysis of cross section and panel data. Cambridge, MA: MIT Press

Xenos, M., \& Foot, K. (2005). Politics as Usual or Politics Unusual? Position Taking and Dialogue on Campaign Websites in the 2002 Elections. Journal of Communication, 55(1),169-185. 
Online campaigning in France 2007-2012: political actors and citizens in the aftermath of the web.2.0 evolution

\section{TABLES}

Table 1. Expenses for online campaign, 2007 and 2012 French presidential elections

\begin{tabular}{|c|c|c|c|c|}
\hline \multirow[b]{2}{*}{ Supporting Party } & \multicolumn{2}{|c|}{2007} & \multicolumn{2}{|c|}{2012} \\
\hline & $\begin{array}{l}\text { Candidate } \\
\text { (\% of votes })\end{array}$ & $\begin{array}{l}\text { Spending } \\
€(\text { in } \% *) \\
\end{array}$ & $\begin{array}{r}\text { Candidate } \\
\text { (\% of votes }) \\
\end{array}$ & $\begin{array}{l}\text { spending } \\
€(\text { in } \%)\end{array}$ \\
\hline $\begin{array}{l}\text { Union for a Popular Movement } \\
\text { (UMP) }\end{array}$ & N. Sarkozy (31.2\%) & $675,571(3.2 \%)$ & N. Sarkozy (27.2\%) & $1,331,846(6 \%)$ \\
\hline Socialist Party (PS) & S. Royal $(25.9 \%)$ & $866,220(4.2 \%)$ & F. Hollande (28.6\%) & $549,251(2.5 \%)$ \\
\hline $\begin{array}{l}\text { Union for French Democracy } \\
(\text { MoDem) }\end{array}$ & F. Bayrou (18.6\%) & $720,511(7.4 \%)$ & F. Bayrou (9.1\%) & $606,363(8 \%)$ \\
\hline National Front (FN) & J. LePen $(10.4 \%)$ & $29,741(.3 \%)$ & M. LePen (17.9\%) & $278,204(3 \%)$ \\
\hline $\begin{array}{l}\text { Revolutionary Communist League } \\
\text { (New Anticapitalist Party since 2009) } \\
\text { (NPA) }\end{array}$ & O. Besancenot (4\%) & $5,404(.05 \%)$ & P. Poutou (1.2\%) & 319 \\
\hline $\begin{array}{l}\text { French Communist Party (Left } \\
\text { Front coalition in 2012) (FdG) }\end{array}$ & M. Buffet (1.9\%) & $107,604(2.2 \%)$ & J. Mélenchon (11.1\%) & $715,603(7.5 \%)$ \\
\hline $\begin{array}{l}\text { The Greens (Europe Écologie-The } \\
\text { Greens since 2009) (EELV) }\end{array}$ & D. Voynet (1.6\%) & $130,172(9 \%)$ & E. Joly $(2.3 \%)$ & $25,056(1.3 \%)$ \\
\hline Workers' Struggle (LO) & A. Laguiller (1.3\%) & $17,212(.08 \%)$ & N. Arthaud (.6\%) & $44,591(4 \%)$ \\
\hline Movement for France (MPF) & P. de Villiers (2.2\%) & $5,485(.01 \%)$ & - & - \\
\hline Anti-globalization activist & J. Bové (1.3\%) & $8,859(.07 \%)$ & - & - \\
\hline $\begin{array}{l}\text { Hunting, Fishing, Nature, Tradition } \\
\text { (CNPT) }\end{array}$ & F. Nihous $(1.2 \%)$ & $2,543(.03 \%)$ & - & - \\
\hline Workers' Party & G. Schivardi $(.3 \%)$ & $664(.001 \%)$ & - & - \\
\hline Arise the Republic (DR) & - & & $\begin{array}{r}\text { N. Dupont-Aignan } \\
(1.8 \%)\end{array}$ & $3,321(.06 \%)$ \\
\hline Solidarity and Progress (S\&P) & - & & J. Cheminade $(.3 \%)$ & $2,794(.02 \%)$ \\
\hline
\end{tabular}

*Percentage of all expenses for the campaign, - not present in election.

Source: Journal officiel de la République française 31.07.2012.; CNCCFP, Dixième rapport d'activité, 2007. 
Table 2. Online performance of the candidates, AOP for Information provision (IP), Interaction and engagement provision (I\&E), Technological functionality (FT)

\begin{tabular}{|c|c|c|c|c|c|c|c|}
\hline \multicolumn{4}{|l|}{ Candidates 2007} & \multicolumn{4}{|l|}{ Candidates 2012} \\
\hline & IP & $\mathrm{I} \& \mathrm{E}$ & $\mathrm{TF}$ & & IP & $\mathrm{I} \& \mathrm{E}$ & $\mathrm{TF}$ \\
\hline All candidates & .589 & .517 & .667 & & .546 & .460 & .700 \\
\hline N. Sarkozy & .769 & .800 & .750 & N. Sarkozy & .615 & .400 & .500 \\
\hline S. Royal & .692 & .900 & .750 & F. Hollande & .615 & .500 & .750 \\
\hline F. Bayrou & .769 & .700 & 1.00 & F. Bayrou & .615 & .700 & .750 \\
\hline J. LePen & .385 & .100 & .750 & M. LePen & .769 & .400 & .750 \\
\hline O. Besancenot & .615 & .500 & .750 & P. Poutou & .385 & .200 & .750 \\
\hline M. Buffet & .769 & .700 & .750 & J. Mélenchon & .539 & .300 & .750 \\
\hline D. Voynet & .615 & .500 & .750 & E. Joly & .462 & .700 & .750 \\
\hline A. Laguiller & .308 & .200 & .500 & N. Arthaud & .308 & .400 & .750 \\
\hline P. de Villiers & .539 & .400 & .500 & & & & \\
\hline J. Bové & .539 & .800 & .500 & & & & \\
\hline F. Nihous & .539 & .300 & .500 & & & & \\
\hline \multirow[t]{3}{*}{ G. Schivardi } & .539 & .300 & .500 & & & & \\
\hline & & & & N. Dupont-Aignan & .615 & .700 & .500 \\
\hline & & & & J. Cheminade & .536 & .300 & .750 \\
\hline Major & .731 & .850 & .750 & & .615 & .450 & .625 \\
\hline Minor & .589 & .433 & $.833 *$ & & .596 & .525 & .750 \\
\hline Fringe & .549 & .457 & $.571 *$ & & .461 & .400 & .688 \\
\hline Left & .577 & .567 & .625 & & .462 & .350 & .750 \\
\hline Centre & .692 & .600 & .875 & & .539 & .700 & .750 \\
\hline Right & .558 & .400 & .625 & & .635 & .450 & .625 \\
\hline
\end{tabular}

Source: 'Online campaigning project' April 2007 and 2012, CEVIPOF Sciences-Po Paris

*difference between group significant at the $\mathrm{p}<.05$ 
Table 3. Web.2.0 performance of the candidates

\begin{tabular}{lc}
\hline & web.2.0 \\
\hline All candidates & .750 \\
\hline N. Sarkozy & .833 \\
F. Hollande & .833 \\
F. Bayrou & 1.00 \\
M. LePen & .833 \\
P. Poutou & .667 \\
J. Mélenchon & .833 \\
E. Joly & .667 \\
N. Arthaud & .167 \\
N. Dupont-Aignan & 1.00 \\
J. Cheminade & .667 \\
\hline Major & .833 \\
Minor & .833 \\
Fringe & .625 \\
\hline Left & .625 \\
Centre & .833 \\
Right & .833 \\
\hline
\end{tabular}

Source: 'Online campaigning project' April 2012, CEVIPOF Sciences-Po Paris

Note: none of the scores differ with statistical significance $\mathrm{p}<.10$

Table 4. E-engagement and e2-engagement during 2007 and 2012 French Presidential elections, (\% of internet users aged 18 and more)

\begin{tabular}{|c|c|c|c|}
\hline & 2007 & 2012 & change \\
\hline \multicolumn{4}{|l|}{ e-engagement } \\
\hline Transferred political information to others & 26 & 18 & -8 \\
\hline Visited candidates' or parties' website & 23 & 17 & -6 \\
\hline Watched political video & 18 & 22 & 4 \\
\hline Read political blog & 26 & 14 & -12 \\
\hline Participated in discussion on political forums & 6 & 7 & 1 \\
\hline Searched for information about election & 24 & 32 & 8 \\
\hline Searched and resent humoristic political content & 23 & 31 & 8 \\
\hline \multicolumn{4}{|l|}{ e2- engagement } \\
\hline Received political information on social network profile & & 14 & \\
\hline Posted political information on own social network profile & & 6 & \\
\hline Followed election on Twitter & & 4 & \\
\hline Posted information about election on Twitter & & 2 & \\
\hline
\end{tabular}

Source: survey 'Internautes et information' January 2007; 'Mediapolis' March 2012 (ANR 2008 - 2012 project), both CEVIPOF, Sciences-Po Paris.

Note: $62.2 \%$ of the respondent declared having profile on any social network, $11.4 \%$ declared having Twitter account. 
Table 5. Regression analysis. e-engagement and e2-engagement, 2007 and 2012 French Presidential elections

\begin{tabular}{|c|c|c|c|c|c|c|c|c|c|c|}
\hline & \multicolumn{2}{|c|}{$\begin{array}{c}\text { e-engagement } \\
2007\end{array}$} & \multicolumn{2}{|c|}{$\begin{array}{c}\text { e-engagement } \\
2012\end{array}$} & \multicolumn{2}{|c|}{$\begin{array}{c}\text { e2-engagement } \\
2012 \\
\end{array}$} & \multicolumn{2}{|c|}{$\begin{array}{c}\text { e-engagement } \\
2012\end{array}$} & \multicolumn{2}{|c|}{$\begin{array}{c}\text { e2-engagement } \\
2012\end{array}$} \\
\hline & Coef. & & Coef. & & Coef. & & Coef. & & Coef. & \\
\hline Female & $-.250 * *$ & $(.099)$ & -.089 & $(.058)$ & -.066 & $(.123)$ & -.053 & $(.059)$ & .019 & $(.126)$ \\
\hline Age & .022 & $(.056)$ & -.027 & $(.032)$ & $-.338 * * *$ & $(.065)$ & $-.057 *$ & $(.031)$ & $-.409 * * *$ & $(.068)$ \\
\hline Education & -.013 & $(.048)$ & .008 & $(.024)$ & -.059 & $(.056)$ & -.002 & $(.023)$ & -.078 & $(.053)$ \\
\hline Income & $-.053 *$ & $(.032)$ & -.018 & $(.020)$ & -.049 & $(.038)$ & -.024 & $(.019)$ & -.055 & $(.038)$ \\
\hline Social group & $-.201 * *$ & $(.099)$ & -.025 & $(.066)$ & -.077 & (.136) & -.011 & $(.065)$ & -.065 & $(.136)$ \\
\hline \multicolumn{11}{|l|}{ Political attitudes } \\
\hline Interest in politics & $.841 * * *$ & $(.156)$ & $.812^{* * *}$ & $(.092)$ & $.930 * * *$ & $(.181)$ & $.759 * * *$ & $(.092)$ & $.836^{* * *}$ & $(.177)$ \\
\hline Political confidence & -.025 & $(.095)$ & $-.162^{* *}$ & $(.059)$ & $-.408 * * *$ & * $(.116)$ & $-.142^{* *}$ & $(.058)$ & $-.383^{* *}$ & $(.116)$ \\
\hline $\begin{array}{l}\text { Interest in electoral } \\
\text { campaign }\end{array}$ & .102 & $(.147)$ & $.359 * * *$ & $(.059)$ & $.600 * * *$ & $(.138)$ & $.350 * * *$ & $(.058)$ & $.584 * * *$ & $(.137)$ \\
\hline $\begin{array}{l}\text { Propensity to discuss } \\
\text { politics }\end{array}$ & $.729 * * *$ & $(.148)$ & $.795^{* * *}$ & $(.097)$ & $.910 * * *$ & $(.195)$ & $.741 * * *$ & $(.096)$ & $.813 * * *$ & $(.194)$ \\
\hline \multicolumn{11}{|l|}{ Political ideology } \\
\hline Party Proximity & $.381^{* *} *$ & $(.141)$ & $.264 * *$ & $(.104)$ & .292 & $(.200)$ & $.250^{* * *}$ & $(.102)$ & .271 & $(.195)$ \\
\hline Political id left & -.034 & $(.100)$ & .121 & $(.076)$ & .209 & $(.166)$ & .065 & $(.074)$ & .167 & $(.159)$ \\
\hline Political id right & .049 & $(.116)$ & -.024 & $(.080)$ & .084 & $(.179)$ & -.013 & $(.076)$ & .109 & $(.170)$ \\
\hline \multicolumn{11}{|l|}{ Media exposure } \\
\hline Press & .099 & $(.126)$ & $.411 * * *$ & $(.106)$ & $.823 * * *$ & $(.197)$ & $.358^{* * * *}$ & $(.102)$ & $.742 * * *$ & $(.195)$ \\
\hline Radio & -.115 & $(.114)$ & -.028 & $(.077)$ & .034 & $(.174)$ & -.064 & $(.077)$ & -.022 & $(.162)$ \\
\hline Internet & $.539 * * *$ & $(.103)$ & $.321 * * *$ & $(.062)$ & $.453 * *$ & $(.137)$ & $.281 * * *$ & $(.102)$ & $.384 * *$ & $(.137)$ \\
\hline \multicolumn{11}{|l|}{ Online history } \\
\hline Frequent "Historical Users & $.214^{* *}$ & $(.096)$ & $.134 *$ & $(.069)$ & $.284^{*}$ & $(.147)$ & .109 & $(.069)$ & $.245^{*}$ & $(.142)$ \\
\hline Frequent Recent Users & .089 & $(.114)$ & $.158 * *$ & $(.075)$ & $.281 *$ & $(.148)$ & .128 & $(.072)$ & .219 & $(.140)$ \\
\hline \multicolumn{11}{|c|}{ Traditional political engagement } \\
\hline $\begin{array}{l}\text { Offline political } \\
\text { engagement }\end{array}$ & & & & & & & $.222 * *$ & $(.080)$ & .195 & $(.151)$ \\
\hline Voluntary work for party & & & & & & & $.142^{*}$ & $(.086)$ & $.340^{*}$ & $(.196)$ \\
\hline Money donation for party & & & & & & & .446 & $(.082)$ & $.821 * * *$ & $(.166)$ \\
\hline $\begin{array}{l}\text { constant } \\
\text { Wald chi2 }\end{array}$ & $\begin{array}{r}-.939 * * * * \\
279.7\end{array}$ & $(.347)$ & $\begin{array}{r}-1.22 * * * \\
635.3\end{array}$ & (.167) & $\begin{array}{r}-2.23 * * * \\
324.1\end{array}$ & $(.337)$ & $-1.21^{* * *}$ & $\begin{array}{l}(.173) \\
798.5\end{array}$ & $-2.086^{* * *}$ & $\begin{array}{l}(.341) \\
393.5\end{array}$ \\
\hline
\end{tabular}


Appendix

Table 1. Grouping of the variables for the content analysis with Cronbach's Alpha for each scale. Percentage of candidates providing each feature.

\begin{tabular}{|c|c|c|}
\hline & 2007 & 2012 \\
\hline \multicolumn{3}{|l|}{ Information provision (IP) $\alpha=.305$} \\
\hline Program information & $100 \%$ & $100 \%$ \\
\hline Media content & $100 \%$ & $40 \%$ \\
\hline Agenda & $92 \%$ & $80 \%$ \\
\hline Photos & $75 \%$ & $60 \%$ \\
\hline Newsletter & $75 \%$ & $10 \%$ \\
\hline Links (visible) & $75 \%$ & $50 \%$ \\
\hline Political career info & $75 \%$ & $80 \%$ \\
\hline Animated photos & $67 \%$ & $60 \%$ \\
\hline Videos & $58 \%$ & $90 \%$ \\
\hline FAQ & $33 \%$ & $10 \%$ \\
\hline Shop online & $12 \%$ & $40 \%$ \\
\hline Info about hobbies/interests & $12 \%$ & $20 \%$ \\
\hline Info about family & 0 & $60 \%$ \\
\hline \multicolumn{3}{|c|}{ Interaction and engagement provision (I\&E) $\alpha=.631$} \\
\hline Donate money & $75 \%$ & $60 \%$ \\
\hline RSS & $67 \%$ & $60 \%$ \\
\hline Volunteer offline & $58 \%$ & $80 \%$ \\
\hline Volunteer online & $50 \%$ & $60 \%$ \\
\hline Commenting on the website & $42 \%$ & $30 \%$ \\
\hline Additional candidate blog & $42 \%$ & $30 \%$ \\
\hline Polls & $42 \%$ & 0 \\
\hline Online debate & $25 \%$ & 0 \\
\hline Share with others & $25 \%$ & $90 \%$ \\
\hline Contact e-mail/post & $83 \%$ & $35 \%$ \\
\hline \multicolumn{3}{|c|}{ Technological functionality (TF) $\alpha=-.667$} \\
\hline Website working without problems & $100 \%$ & $100 \%$ \\
\hline Download possibilities & $100 \%$ & $90 \%$ \\
\hline Search engine & $33 \%$ & $90 \%$ \\
\hline Facilities for handicapped & $33 \%$ & 0 \\
\hline \multicolumn{3}{|l|}{ Web.2.0 $\alpha=.636$} \\
\hline Microblog profile & & $90 \%$ \\
\hline Social network profile & & $80 \%$ \\
\hline Online contact form & & $70 \%$ \\
\hline Video sharing site & & $60 \%$ \\
\hline Photo sharing site & & $40 \%$ \\
\hline
\end{tabular}


Table 2. Wording, coding and frequencies of the most important questions from the surveys used in the questionnaire:

Dependent variables

Formulation of the question $\quad$ Variable recoding

\begin{tabular}{|c|c|c|}
\hline e-engagement & $\begin{array}{l}\text { In } 2007 \text { the question was phrased "Among all the following activities, please } \\
\text { mark those that you have already performed on political websites". In } 2012 \\
\text { "Here are different activities that one can perform online. For each of the } \\
\text { following elements please tell me if you performed it ..." } \\
\text { Transferred political information to others } \\
\text { Visited candidates' or parties' website } \\
\text { Watched political video } \\
\text { Read political blog } \\
\text { Participated in discussion on political forums } \\
\text { Searched for information about election } \\
\text { Searched and resent humoristic political content }\end{array}$ & $\begin{array}{l}\text { Each item as a dummy variable: } \\
\text { performed X (1), otherwise }(0) \\
\text { Coded: into index - sum of all } \\
\text { activities, continuous variable }\end{array}$ \\
\hline e2-engagement & $\begin{array}{l}\text { "Have you already: } \\
\text { Received political information on social network profile } \\
\text { Posted political information on own social network profile } \\
\text { Followed election on Twitter } \\
\text { Posted information about election on Twitter" }\end{array}$ & $\begin{array}{l}\text { Each item as a dummy variable: } \\
\text { performed X (1), otherwise }(0) \\
\text { Coded: into index - sum of all } \\
\text { activities, continuous variable }\end{array}$ \\
\hline
\end{tabular}

Independent variables

Formulation of the question

Recoding into variable

\begin{tabular}{|c|c|c|}
\hline Female & Are you? & $\begin{array}{l}\text { Female (1) 47\% (2007), 48\% (2012); } \\
\text { Male (0) 53\% (2007), 52\% (2012); }\end{array}$ \\
\hline Age & What is your age? & $\begin{array}{l}\text { Grouped cohorts: } \\
18-24,25-34,35-49,50+\end{array}$ \\
\hline Education & $\begin{array}{l}\text { What is the highest level of the diploma that you } \\
\text { obtained? }\end{array}$ & Ordinal scale of eight levels \\
\hline Income & $\begin{array}{l}\text { In which income group (net per month) is your } \\
\text { household? }\end{array}$ & Ordinal scale of six levels \\
\hline Social group & $\begin{array}{l}\text { What is you actual profession (or What was your } \\
\text { profession before retirement)? }\end{array}$ & Working as white collar (1) otherwise (0) \\
\hline Interest in politics & "Are you interested in politics?" & $\begin{array}{l}4 \text { items scale recoded into: interested in politics (1) } 60 \% \\
(2007), 48 \% \text { (2012); otherwise (0) }\end{array}$ \\
\hline $\begin{array}{l}\text { Satisfaction with } \\
\text { democracy }\end{array}$ & $\begin{array}{l}\text { "Would you say that the democracy in France is } \\
\text { functioning very well, rather well, rather badly, very } \\
\text { badly?" it is a question traditionally used in French } \\
\text { electoral studies as explicative variable of electoral } \\
\text { /political participation. }\end{array}$ & $\begin{array}{l}4 \text { items scale recoded into: Having confidence in } \\
\text { functioning of the French democracy (1) } 53 \% \text { (2007), } \\
48 \% \text { (2012); otherwise (0). }\end{array}$ \\
\hline $\begin{array}{l}\text { Interest in electoral } \\
\text { campaign }\end{array}$ & $\begin{array}{l}\text { "You personally, are you interested by the Presidential } \\
\text { elections?" } \\
\text { "Do you follow French Presidential elections closely" } \\
\text { (2012) }\end{array}$ & $\begin{array}{l}4 \text { items scale recoded into: Interested and followed the } \\
\text { campaign (1) } 62 \% \text { (2007), } 49 \% \text { (2012); otherwise (0) }\end{array}$ \\
\hline $\begin{array}{l}\text { Propensity to discuss } \\
\text { politics }\end{array}$ & $\begin{array}{l}\text { In } 2007 \text { respondents were asked "Are you willing to } \\
\text { take part in the political debate that will take place } \\
\text { during the Presidential elections", in } 2012 \text { "Do you } \\
\text { discuss politics with people surrounding you" }\end{array}$ & $\begin{array}{l}4 \text { items scales recoded into: both questions were recoded } \\
\text { into dummy variable 'yes, I discuss politics' (1), } 58 \% \\
(2007), 67 \% \text { (2012); otherwise (0) }\end{array}$ \\
\hline Party Proximity & $\begin{array}{l}\text { "Here is the list of political movements. Could you } \\
\text { please tell me to which one of them you feel closes to } \\
\text {..... (Party x, Party y, Party z, Other, None)." }\end{array}$ & $\begin{array}{l}\text { Recoded to a dummy variable: respondent identified a } \\
\text { party which he/she feels closer to (1) } 73 \% \text { (2007), } 71 \% \\
\text { (2012); otherwise (0). }\end{array}$ \\
\hline Political id left & $\begin{array}{l}\text { "Would you say that you situate yourself more to the } \\
\text { left, more to the right, or neither left nor right?" }\end{array}$ & $\begin{array}{l}\text { Recoded to set of binary variables: } \\
\text { I feel more on the left (1) } 28 \% \text { (2007), 30\% (2012); } \\
\text { I feel more on the right (1) } 22 \% \text { (2007), } 25 \%(2012) \text {; } \\
\text { Reference group: I feel more in the center or neither left } \\
\text { nor right } 49 \% \text { (2007), } 44 \%(2012)\end{array}$ \\
\hline Media exposure & $\begin{array}{l}\text { "Generally speaking, which media do you use the most } \\
\text { frequently to obtain political information: Television, } \\
\text { Radio, Internet, National print press, Regional print } \\
\text { press, Free newspapers, Other, None" }\end{array}$ & $\begin{array}{l}\text { Only one choice possible. Variable recoded to set of } \\
\text { binary variable. } \\
\text { Television } 46 \% \text { (2007), 54\% (2012) (reference group); } \\
\text { Radio } 18 \% \text { (2007), 14\% (2012); } \\
\text { Print press (on general) } 10 \%(2007), 7 \%(2012) \text {; } \\
\text { Internet (pure players, general portals yahoo, google } \\
\text { news) } 9.5 \% \text { (2007), 20\% (2012). }\end{array}$ \\
\hline Online history & $\begin{array}{l}\text { Index created out of two questions: } \\
\text { "Since when do you use Internet" } \\
\text { And "How often do you use Internet" }\end{array}$ & $\begin{array}{l}4 \text { groups of Internet users are created: } \\
\text { 1. Frequent Historical users (FH)- those using the } \\
\text { Internet for more than } 7 \text { years (for 2007) or } 12 \text { years (for } \\
2012 \text { ) and more than one time per day, 27\% (2007), } \\
32 \%(2012) \text {; } \\
\text { 2. Frequent Recent users (FR) - those using the Internet } \\
\text { for } 5 \text { to } 7 \text { years (for 2007) or } 10 \text { to } 12 \text { years (for 2012) } \\
\text { and more than one time per day, } 23 \% \text { (2007), 21\% } \\
(2012) \text {; }\end{array}$ \\
\hline
\end{tabular}




$\begin{array}{lll}\begin{array}{l}\text { Offline political } \\ \text { engagement }\end{array} & \begin{array}{l}\text { Question asked only in 2012 survey "For the following } \\ \text { political activities, please indicate if you have done any } \\ \text { of them: participated in political meeting, contacted } \\ \text { politician, sign a petition, strike, participated in riots, } \\ \text { occupied a place, boycotted products" }\end{array} & \begin{array}{l}\text { Variable recoded into dummy if any of the activities } \\ \text { were performed, 70\% (2012) }\end{array} \\ \begin{array}{ll}\text { Question asked only in 2012 survey "Have you already: } \\ \text { poluntary work for } \\ \text { party }\end{array} & \begin{array}{l}\text { Dummy variable: } \\ \text { distributed leaflets, posting posters)?" }\end{array} & \text { Yes, 9\% } \\ \begin{array}{l}\text { Monestion asked only in 2012 survey "Have you already: } \\ \text { party }\end{array} & \begin{array}{l}\text { Dummy variable: } \\ \text { supported financially a party" }\end{array} & \text { Yes, 7\% }\end{array}$

3. Frequent New users (FN) - those using the Internet less than 5 years (for 2007) or 10 years (for 2012) and more than one time per day, 29\% (2007), 28\% (2012) (reference group);

4. Sporadic users - those using the Internet less often than once daily, 24\% (2007), 13\% (2012) (reference group)

Variable recoded into dummy if any of the activities of them: participated in political meeting, contacted occupied a place, boycotted products"

Question asked only in 2012 survey "Have you already: distributed leaflets, posting posters)?"

party supported financially a party”'

Yes, $7 \%$

Table 3. Growth of Internet users in France 1998-2011 (\%)

\begin{tabular}{cc} 
year & \% of Internet users \\
\hline 1998 & 6 \\
1999 & 9 \\
2000 & 14 \\
2001 & 26 \\
2002 & 30 \\
2003 & 36 \\
2004 & 39 \\
2005 & 43 \\
2006 & 47 \\
2007 & 66 \\
2008 & 71 \\
2009 & 72 \\
2010 & 80 \\
2011 & 80 \\
2012 & 83 \\
\hline
\end{tabular}

Source: http://data.worldbank.org/indicator/IT.NET.USER.P2 